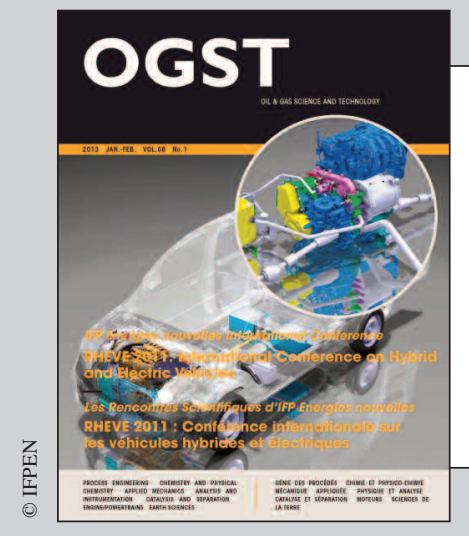

Dossier

This paper is a part of the hereunder thematic dossier published in OGST Journal, Vol. 68, No. 1, pp. 3-178 and available online here

Cet article fait partie du dossier thématique ci-dessous publié dans la revue OGST, Vol. 68, n 1 , pp. 3-178 et téléchargeable ici

DOSSIER Edited by/Sous la direction de : A. Sciarretta, F. Badin et J. Bernard RHEVE 2011 : International Conference on Hybrid and Electric Vehicles RHEVE 2011 : Conférence internationale sur les véhicules hybrides et électriques

Oil \& Gas Science and Technology - Rev. IFP Energies nouvelles, Vol. 68 (2013), No. 1, pp. 3-178

Copyright (C) 2013, IFP Energies nouvelles

\section{$3>$ Editorial}

$13>$ Analysis and Experimental Implementation of a Heuristic Strategy for Onboard Energy Management of a Hybrid Solar Vehicle

Analyse et expérimentation d'une stratégie heuristique pour la gestion d'énergie à bord d'un véhicule hybride solaire

G. Coraggio, C. Pisanti, G. Rizzo and M. Sorrentino

23 > Open Issues in Supervisory Control of Hybrid Electric Vehicles: A Unified Approach Using Optimal Control Methods

Questions ouvertes sur la supervision énergétique des véhicules hybrides électriques : une approche unifiée par la théorie de la commande optimale

L. Serrao, A. Sciarretta, 0. Grondin, A. Chasse, Y. Creff, D. Di Domenico, P. Pognant-Gros, C. Querel and L. Thibault

35 > Optimization of Hybrid Power Trains by Mechanistic System Simulations

Optimisation de groupes motopropulseurs électriques hybrides par simulation du système mécanique

T. Katrašnik and J.C. Wurzenberger

51 > A Phenomenological Heat Transfer Model of SI Engines - Application to the Simulation of a Full-Hybrid Vehicle

Un modèle phénoménologique de transfert thermique au sein de moteurs à allumage commandé - Application à la simulation d'un véhicule full-hybride

R. Dubouil, J.-F. Hetet and A. Maiboom

$65>$ Battery Electric Vehicle (BEV) or Range Extended Electric Vehicle (REEV)? - Deciding Between Different Alternative Drives Based on Measured Individual Operational Profiles

Véhicule électrique à batteries (BEV) ou véhicule électrique à prolongateur d'autonomie (REEV) ? - Choisir entre différents entrânements alternatifs sur la base de profils opérationnels individuels mesurés

S. Marker, B. Rippel, P. Waldowski, A. Schulz and V. Schindler

$79>$ Assessment by Simulation of Benefi ts of New HEV Powertrain Configurations

Évaluation par simulation des bénéfi ces de nouvelles chaînes de traction hybrides

N. Kim and A. Rousseau
95 > Dual Mode Vehicle with In-Wheel Motor: Regenerative Braking Optimization

Véhicule bi-mode avec moteurs roues : optimisation du freinage récupératif

G. Le Solliec, A. Chasse, J. Van-Frank and D. Walser

109 > Engine Downsizing and Electric Hybridization Under Consideration of Cost and Drivability

Réduction de taille moteur et hybridation électrique avec considérations de coût et de performance de conduite

S. Ebbesen, P. Elbert and L. Guzzella

117 > Representative Midwestern US Cycles: Synthesis and Applications Cycles représentatifs du Middle West américain : synthèse et applications

T.-K. Lee and Z.S. Filipi

127 > A Review of Approaches for the Design of Li-lon BMS Estimation Functions

Revue de différentes approches pour l'estimation de l'état de charge de batteries Li-ion

D. Di Domenico, Y. Creff, E. Prada, P. Duchêne, J. Bernard and V. Sauvant-Moynot

137 > Experimental Assessment of Battery Cycle Life Within the SIMSTOCK Research Program

Évaluation expérimentale de la durée de vie de la batterie dans le programme de recherche SIMSTOCK

P. Gyan, P. Aubret, J. Hafsaoui, F. Sellier, S. Bourlot, S. Zinola and F. Badin

$149>$ Smart Battery Thermal Management for PHEV Efficiency Une gestion avancée de la thermique de la batterie basse tension de traction pour optimiser l'efficacité d'un véhicule hybride électrique rechargeable

L. Lefebvre

$165>$ Parameterization and Observability Analysis of Scalable Battery Clusters for Onboard Thermal Management

Paramétrage et analyse d'observabilité de clusters de batteries de taille variable pour une gestion thermique embarquée

Xinfan Lin, Huan Fu, Hector E. Perez, Jason B. Siege, Anna G. Stefanopoulou, Yi Ding and Matthew P. Castanier 
Oil \& Gas Science and Technology - Rev. IFP Energies nouvelles, Vol. 68 (2013), No. 1, pp. 3-12

Copyright (C) 2013, IFP Energies nouvelles

DOI: $10.2516 /$ ogst/2013112

\section{Éditorial}

\section{LES RENCONTRES SCIENTIFIQUES D'IFP ENERGIES NOUVELLES RHEVE 2011 : CONFÉRENCE SCIENTIFIQUE INTERNATIONALE SUR LES VÉHICULES HYBRIDES ET ÉLECTRIQUES}

\section{INTRODUCTION}

Ce numéro spécial contient une série d'articles qui ont été sélectionnés à l'issue de la rencontre scientifique RHEVE 2011 d'IFP Energies nouvelles sur les véhicules hybrides et électriques dont ce fut la seconde édition. La conférence, qui a eu lieu les 6 et 7 décembre 2011 sur le site d'IFP Energies nouvelles à Rueil-Malmaison, s'est concentrée sur les dernières évolutions technologiques dans le domaine des véhicules hybrides et électriques. Les correspondants scientifiques de cet événement étaient Antonio Sciarretta, François Badin et Julien Bernard (IFP Energies nouvelles). Avec plus de 100 participants venus de 10 pays, RHEVE 2011 a réuni des experts de diverses origines (industrie, instituts de recherche, universités, doctorants, etc.), pour discuter d'un large éventail de sujets : architectures et composants spécifiques, simulation et évaluation en service, gestion à bord et optimisation des systèmes de stockage de l'énergie. Ce numéro regroupe donc un ensemble de résultats scientifiques et d'avancées dans plusieurs domaines conduisant à des progrès importants pour le développement des futurs véhicules.

\section{DÉFIS POUR LA CONCEPTION DES VÉHICULES DU FUTUR}

L'ingénierie et la conception des véhicules du futur sont des tâches extrêmement stimulantes et, pour un ingénieur et un chercheur, il est fantastique de pouvoir y contribuer. En particulier, les défis sont de trouver des compromis optimaux pour concevoir un véhicule offrant, à un coût raisonnable pour son propriétaire, du confort lors de son utilisation et dans le même temps minimisant l'impact sur l'environnement. Ce dernier est souvent formulé en termes de réponses satisfaisantes aux demandes des législateurs quant à la consommation de carburant (c'est-à-dire aux émissions de $\mathrm{CO}_{2}$ liées à l'utilisation de combustibles fossiles) et quant aux limitations sur les gaz d'échappement. Il s'agit d'une tâche non triviale dans le domaine de l'ingénierie des systèmes et il n'y a pas de solution globale simple disponible. Nos objectifs comme ingénieurs et chercheurs sont d'identifier et de résoudre les différents verrous rencontrés aux différentes étapes devant conduire à une solution globale.

Des incitations apparaissent pour réduire les émissions globales de $\mathrm{CO}_{2}$ (Fig. 1), qui nécessiteront des efforts pour réduire l'utilisation des ressources limitées en combustibles fossiles et leur impact environnemental. 


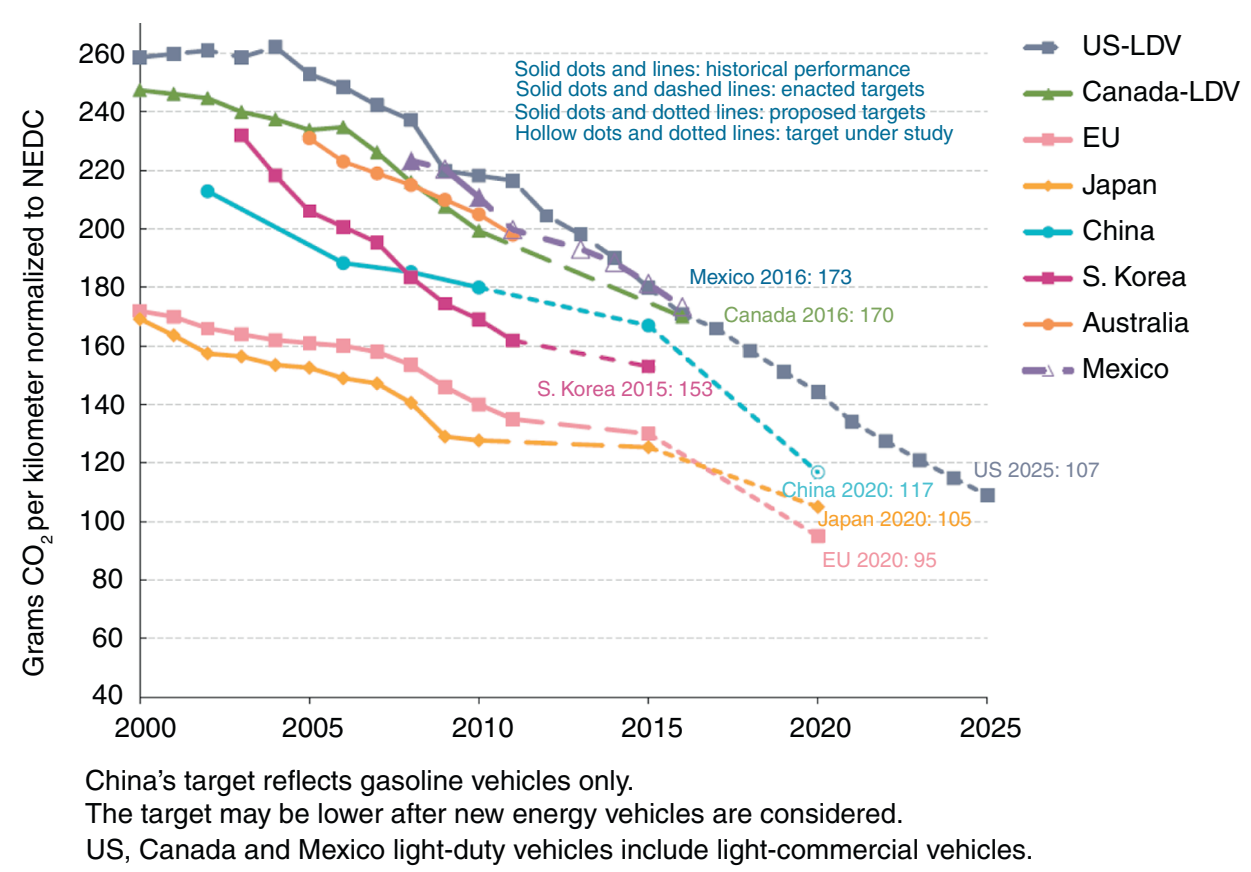

Figure 1

Émissions mondiales de $\mathrm{CO}_{2}$, données historiques et futures normes.

Source: Conseil international des transports propres (ICCT).

Parmi les chemins disponibles pour la réduction des émissions de $\mathrm{CO}_{2}$, nous pouvons mentionner les suivants :

- des composants de véhicules plus efficaces (aérodynamisme, pneumatiques, véhicules plus légers, moteurs, etc.);

- des motorisations alternatives plus efficaces;

- des mélanges de carburants à émission neutre de $\mathrm{CO}_{2}$ (méthanol, éthanol, etc.) ou l'électricité comme dans véhicules électriques et hybrides rechargeables.

Dans l'optique d'atteindre ces objectifs visant une solution économique de transport et attrayante pour le propriétaire du véhicule, il est évident qu'une solution unique n'est pas disponible. Les thèmes essentiels de ce numéro spécial d'OGST sont donc l'ingénierie des systèmes et l'optimisation : les articles figurant dans cette publication contribuent tous à ces domaines en élargissant la base des connaissances scientifiques, en développant de nouvelles théories, et en présentant des démonstrations de nouvelles technologies.

Des outils de modélisation et de simulation dans le domaine des groupes motopropulseurs électrifiés sont de nos jours disponibles apportant une aide importante dans le processus de conception du véhicule. Leur utilisation s'étend de l'analyse de la conception des composants (explorant les détails les plus profonds d'un composant et générant une connaissance détaillée), au système complet du véhicule (pour l'explorer et le dimensionner). Même si la modélisation et la simulation sont des outils usuels, des défis subsistent. Par exemple, il existe toujours un écart entre les modèles de composants, qui peuvent être exigeants en moyen de calcul, et les systèmes modèles qui font appel à des versions simplifiées des composants. Un défi est de permettre l'utilisation du modèle et sa diffusion dans la chaîne de développement du produit afin que les connaissances générées dans le développement d'un composant puissent être utilisées efficacement dans la modélisation ultérieure du système et lors des étapes de simulation. 
À coté de la modélisation qui est un thème commun à de nombreuses présentations de cette conférence, nous avons classé dans cet éditorial les articles selon les grands domaines suivants : contrôle de supervision, approche multidomaine, configurations du groupe motopropulseur et optimisation, cycles de conduite, modélisation et estimation de l'état des batteries.

\section{ARTICLES}

\subsection{Contrôle de supervision}

Une approche fréquemment utilisée pour résoudre les problèmes liés à la coexistence de modèles pointus et simplifiés consiste à utiliser une séparation des échelles de temps et à ne modéliser que ceux qui sont importants, puis à simplifier les plus rapides comme des fonctions statiques et les plus lents comme des constantes.

Parmi les papiers de ce numéro spécial, certains utilisent ces idées. Par exemple G. Coraggio, C. Pisanti, G. Rizzo et M. Sorrentino («Analyse et expérimentation d'une stratégie heuristique pour la gestion d'énergie à bord d'un véhicule hybride solaire ») séparent le problème de la modélisation du contrôle optimal en sous-problèmes différents dont un est le chargement de la batterie à partir de l'énergie solaire, qui est un processus lent, et un autre étant le processus de décharge qui est rapide. Chaque sous-problème est modélisé et l'ensemble du système est alors optimisé donnant une solution efficace pour contrôler la supervision du véhicule.

Un autre domaine important est celui de la complexité accrue du système et comment il peut être systématiquement manipulé avec des méthodes basées sur des modèles. Le document de L. Serrao, A. Sciarretta, O. Grondin, A. Chasse, Y. Creff, D. Di Domenico, P. Pognant-Gros, C. Querel et L. Thibault («Questions ouvertes sur la supervision énergétique des véhicules hybrides électriques : une approche unifiée par la théorie de la commande optimale »), étend la stratégie basée sur la minimisation de consommation équivalente (Equivalent Consumption Minimization Strategy, ECMS) et il montre comment elle peut être utilisée pour gérer des motorisations plus complexes, comme par exemple les contraintes de rechargement de véhicules électriques. Ce papier apporte également une contribution dans le domaine du contrôle de la supervision.

\subsection{Approches multidomaines}

Les systèmes de transmission couvrent par nature de nombreux domaines : la mécanique, la thermodynamique, la mécanique des fluides, la chimie, ainsi que le contrôle et l'informatique. Les technologies automobiles innovantes sont de plus en plus complexes et elles combinent des composants de plus en plus nombreux et variés ; leur conception et leur contrôle à bord nécessitent une approche globale et des systèmes de gestion sophistiqués pouvant être fournis par des systèmes de contrôle modernes. De nouvelles contributions dans ce domaine sont données par T. Katrašnik et J.C. Wurzenberger (« Optimisation de groupes motopropulseurs électriques hybrides par simulation du système mécanique ») et par R. Dubouil, J.-F. Hetet et A. Maiboom («Un modèle phénoménologique de transfert thermique au sein de moteurs à allumage commandé - application à la simulation d'un véhicule entièrement hybride »). Ces deux articles développent des modèles multidomaines pour les véhicules hybrides prenant en compte dans la modélisation les aspects mécaniques, thermodynamiques ainsi que les effets chimiques. Une approche traditionnelle a été de traiter séparément la consommation de carburant et les émissions, mais du fait des limitations d'émission plus strictes des véhicules, cela conduit à des stratégies sous optimisées. Par conséquent, une intégration de l'optimisation de l'énergie en lien avec le système d'émission est nécessaire, ce qui est pris en compte dans les papiers mentionnés ci-dessus. 


\subsection{Configurations du groupe motopropulseur et optimisation}

Le choix des composants dans le groupe motopropulseur a un effet direct sur la performance du véhicule et il est nécessaire de rechercher un large espace pour la conception et d'évaluer les concepts par rapport à différents critères. Le papier de S. Marker, B. Rippel, P. Waldowski, A. Schulz et V. Schindler ("Véhicule électrique à batteries (BEV) ou véhicule électrique à prolongateur d'autonomie (REEV)? - Choisir entre différents entraînements alternatifs sur la base de profils opérationnels individuels mesurés ») et celui de N. Kim et A. Rousseau («Évaluation par simulation des bénéfices de nouvelles chaînes de traction hybrides ») évaluent le potentiel de différents concepts. L'article de G. Le Solliec, A. Chasse, J. Van-Franck et D. Walser ("Véhicule bi-mode avec moteurs roues : optimisation du freinage récupératif ») étudie également l'optimisation de la conception et des composants.

Une approche pour optimiser les critères déroutants et contradictoires est étudiée par S. Ebbesen, P. Elbert et L. Guzzella ("Réduction de taille moteur et hybridation électrique avec considérations de coût et de performance de conduite »). Dans la conception, il y a souvent des objectifs contradictoires et une analyse de Pareto est utilisée dans ce document pour illustrer et analyser les compromis entre des conceptions différentes et leurs implications sur différents critères concurrents.

\subsection{Cycles de conduite}

Les cycles de conduite standard, qui sont utilisés pour les essais d'émissions et pour l'estimation de la consommation de carburant, diffèrent de la conduite réellement pratiquée et un concept doit donc être évalué pour d'autres cycles. Une approche basée sur des cycles de synthèse simulant le comportement statistique issu de données réelles, est élaboré et évalué par T.-K. Lee et Z.S. Filipi (« Cycles représentatifs du Middle West américain : synthèse et applications »). Ces habitudes de conduite sont ensuite utilisées pour évaluer l'effet que le rechargement des véhicules électriques hybrides peut avoir sur le réseau électrique.

\subsection{Modélisation et estimation de l'état des batterie}

Finalement, il est important d'aborder dans ce numéro spécial les batteries car elles sont cruciales pour les véhicules électriques et hybrides. En général, l'état de charge de la batterie est difficile à estimer et la contribution de D. Di Domenico, Y. Creff, E. Prada, P. Duchêne, J. Bernard et V. Sauvant-Moynot (« Revue de différentes approches pour l'estimation de l'état de charge de batteries Li-ion ») est une revue comparant différentes méthodes d'estimation de l'état de charge. Concevoir et contrôler des batteries de véhicules est un défi difficile pour lequel une recherche fondamentale est nécessaire. Un exemple en est la synthèse des résultats issus d'un projet de recherche orienté sur l'expérimentation donnée par P. Gyan, P. Aubret, J. Hafsaoui, F. Sellier, S. Bourlot, S. Zinola et F. Badin (« Évaluation expérimentale de la durée de vie de la batterie dans le programme de recherche SIMSTOCK») : la capacité et le vieillissement y ont été étudiés donnant à la fois de nouveaux résultats sur le vieillissement et des orientations pour explorer de nouvelles zones de recherche.

Conjointement avec les phénomènes de charge et de décharge, les effets thermiques affectent la durée de vie de la batterie. Le suivi et le contrôle des états thermiques ont été pris en compte dans les travaux de $\mathbf{L}$. Lefebvre ("Une gestion avancée de la thermique de la batterie basse tension de traction pour optimiser l'efficacité d'un véhicule hybride électrique rechargeable »). Une motivation similaire se cache derrière le travail de Xinfan Lin, Huan Fu, Hector E. Perez, Jason B. Siegel, Anna G. Stefanopoulou, Yi Ding et Matthew P. Castanier ( Paramétrage et analyse d'observabilité de clusters de batteries de taille variable pour une gestion thermique embarquée »), qui développe un modèle pour l'état thermique d'une batterie et 
d'un pack de batterie. Un apport important de ce papier est qu'il montre que le modèle peut être paramétré en ligne et que la méthodologie présentée est extensible aux packs de batteries.

\section{CONCLUSION}

Par son ensemble, ce numéro d'OGST propose une collection d'articles qui couvrent les différents domaines de la conception et de l'optimisation des véhicules électriques et hybrides. Il montre clairement des développements passionnants qui sont en cours dans de nombreux domaines. De plus, ces contributions soulignent également la nécessité et l'importance d'une interaction entre différents domaines scientifiques pour la recherche et le développement de véhicules d'un futur respectueux de l'environnement.

Lars Eriksson

Vehicular Systems, Department of Electrical Engineering

Linköping Uninversity

58183 Linköping

Sweden 



\section{Editorial}

\section{LES RENCONTRES SCIENTIFIQUES D'IFP ENERGIES NOUVELLES RHEVE 2011: INTERNATIONAL SCIENTIFIC CONFERENCE ON HYBRID AND ELECTRIC VEHICLES}

\section{INTRODUCTION}

This issue contains a collection of papers that have been selected from the conference "Les rencontres scientifiques d'IFP Energies nouvelles: International Scientific Conference on Hybrid and Electric Vehicles (RHEVE 2011)", which is IFPEN's second RHEVE scientific conference. The conference focuses on recent technological developments in the field of hybrid and electric vehicles and took place on 6 and 7 December 2011 at the IFPEN, Rueil-Malmaison site, France. The event was led by Antonio Sciarretta, François Badin and Julien Bernard in their capacity as scientific correspondents. With over 100 participants from 10 countries and a variety of backgrounds (industry, research institutes, universities, doctoral students, etc.), RHEVE 2011 brought together experts to discuss a range of topics: architectures and specific components, simulation and assessment during use, energy storage systems and on-board energy management and optimization. Altogether this issue brings together scientific results and reports of progress from several areas that constitute important progress for the development of future vehicles.

\section{ENGINEERING CHALLENGES OF FUTURE VEHICLES}

The engineering and design of the vehicles for the future are tremendously challenging tasks, and as an engineer and researcher it is fantastic to be able to take part in and contribute to it. In essence, the challenges lies in finding the optimal trade-offs that can deliver a vehicle that gives comfortable transportation, has a good total economy for the owner and, at the same time, minimizes the impact on the environment. The latter is often formulated in terms of meeting the legislators demands on fuel consumption (i.e. $\mathrm{CO}_{2}$ emissions that is related to fossil fuel usage) and limitations on gaseous exhaust emission. This is a non-trivial task in the field of systems engineering and there is no simple global solution available and our tasks as engineers and researchers is to identify and solve relevant subproblems that constitute steps towards a global solution.

Globally incentives are appearing for reducing the $\mathrm{CO}_{2}$ emissions, see Figure 1, which is the result of an effort to reducing the usage of the limited resources of fossil-fuels and also reducing its environmental impact.

Some available paths towards $\mathrm{CO}_{2}$ reduction are:

- more efficient vehicle components (aerodynamics, tyres, lighter vehicles, engines, etc.);

- more efficient alternative powertrains;

- blending the vehicle's energy delivery with $\mathrm{CO}_{2}$ neutral energy sources (methanol, ethanol, etc.) or electricity as in electric and plug-in hybrid vehicles. 


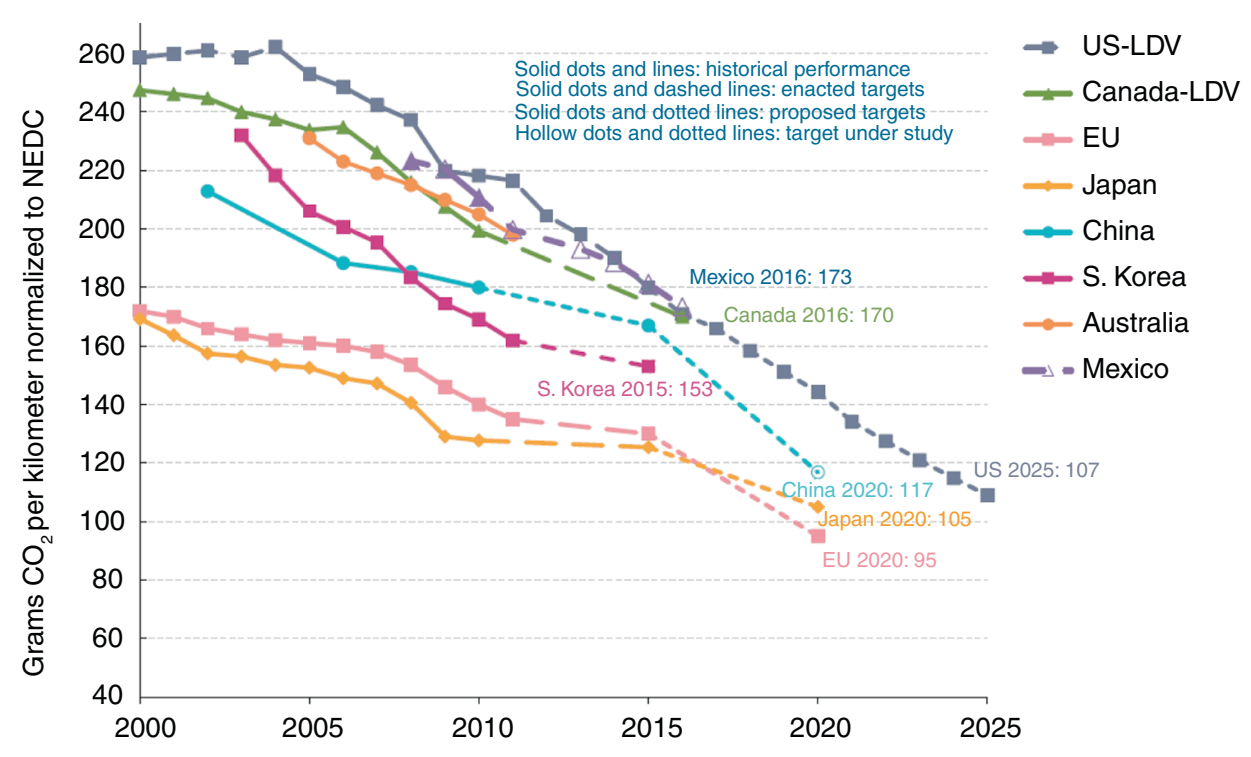

China's target reflects gasoline vehicles only. The target may be lower after new energy vehicles are considered. US, Canada and Mexico light-duty vehicles include light-commercial vehicles.

Figure 1

Global $\mathrm{CO}_{2}$ emissions, historical data and future standards.

Source: The International Council on Clean Transportation (ICCT).

When aiming at achieving these goals, together with the previously mentioned goals of an economic and attractive transportation solution for a car owner, it is apparent that one single solution isn't available. The essential topics is therefore systems engineering and optimization and the papers included in this issue all contribute to this field by widening the scientific knowledge base, developing new theory, and demonstrating new technologies.

Modeling and simulation tools in the field of electrified powertrains are nowdays commodities and are an important aid in the vehicle design process. Its usage spans from component analysis and design that explores the deeper details of a component and generates detailed knowledge, to complete vehicle system that is used to explore and dimension the total system. Even though modeling and simulation is a commodity there are challenges remaining. For example, there is still a gap between the component models that can be computationally demanding and system models that have simpler versions of the components. A challenge is to enable model usage and propagation in the product development chain so that the knowledge generated in the development of a component can efficiently be utilized in the subsequent system modeling and simulation steps.

Besides modeling, which is a common theme in many presentations of this conference, we have in this editorial classified the contributions according to the following areas: supervisory control, multi-domain handling, powertrain configurations and optimization, driving cycles, modeling and estimation of battery state.

\section{PAPERS}

\subsection{Supervisory Control}

A frequently used approach for tackling the problem related to advanced and simplified models is to use a separation of time scales and only model those that are important for 
the problem at hand and then simplify the faster ones as static functions and slower ones as (slowly varying) constants.

Among the works in this issue there are some that use these ideas. For example, G. Coraggio, C. Pisanti, G. Rizzo and M. Sorrentino ("Analysis and Experimental Implementation of a Heuristic Strategy for On-Board Energy Management of a Hybrid Solar Vehicle") separates the modeling for the optimal control problem in different subproblems where one is the charging of the battery from solar power, which is a slow process, and the driving and discharge which are fast processes. Each subproblem is modeled and the total system is then optimized giving an efficient solution for a supervisory control of the vehicle.

Another important area is that of the increased system complexity and how it can be handled systematically with model-based methods. The included paper L. Serrao, A. Sciarretta, O. Grondin, A. Chasse, Y. Creff, D. Di Domenico, P. Pognant-Gros, C. Querel and L. Thibault ("Open Issues in Supervisory Control of Hybrid Electric Vehicles: A Unified Approach Using Optimal Control Methods"), extends the basic Equivalent Consumption Minimization Strategy (ECMS) and shows how it can be used to handle more complex powertrains, constraints like for example plug-in electric vehicles. This is also a contribution in the area of supervisory control that was mentioned above.

\subsection{Multi-Domain Handling}

Powertrain systems are inherently multi-domain covering mechanic, thermodynamic, fluid mechanic, chemical, as well as controls and computer science. The innovative vehicle technologies are becoming more complex and combine components that are becoming more numerous and more varied, their design and on-board control require a global system approach and sophisticated management that the modern control systems can provide. New contributions in this area are given in T. Katrašnik and J.C. Wurzenberger ("Optimization of Hybrid Power Trains by Mechanistic System Simulations") and R. Dubouil, J.-F. Hetet and A. Maiboom ("A Phenomenological Heat Transfer Model of SI Engines Application to the Simulation of a Full-Hybrid Vehicle"). These two papers develop multidomain models for hybrid vehicles and include mechanic, thermodynamic and well as chemical effects in the modeling. A traditional approach has been to treat fuel consumption separately from the emissions but with the increasingly stringent emission limits on vehicles this can result in sub optimal strategies. Therefore an integration of the energy optimization and emission system is needed and this is considered in the papers mentioned above.

\subsection{Powertrain Configurations and Optimization}

The choice of components in the powertrain has a direct effect on the resulting vehicle performance and it is necessary to search a large design space and evaluate the concepts with respect to different criteria. The papers S. Marker, B. Rippel, P. Waldowski, A. Schulz and V. Schindler ("Battery Electric Vehicle (BEV) or Range Extended Electric Vehicle (REEV)? - Deciding Between Different Alternative Drives Based on Measured Individual Operational Profiles") and N. Kim and A. Rousseau ("Assessment by Simulation of Benefits of New HEV Powertrain Configurations") assess the potential of different concepts while G. Le Solliec, A. Chasse, J. Van-Franck and D. Walser ("Dual Mode Vehicle with In-Wheel Motor: Regenerative Braking Optimization") also studies the optimization of the concept and its components.

An approach to optimize the under mixed and conflicting criteria is studied in S. Ebbesen, P. Elbert and L. Guzzella ("Engine Downsizing and Electric Hybridization Under Consideration of Cost and Drivability"). In the design, there are often conflicting goals and a Paretofront is used in the paper to illustrate and analyze the trade-off between different designs and their implications on different competing criteria. 


\subsection{Driving Cycles}

The standard driving cycles that are used for emission testing and fuel consumption estimation differ from real world driving and a concept thus needs to be evaluated on other cycles too. An approach that builds synthetic cycles that mimic the statistical behavior of real world data is developed and evaluated in T.-K. Lee and Z.S. Filipi ("Representative Midwestern US Cycles: Synthesis and Applications"). These driving patterns are then used to evaluate the effect that plug in hybrid electric vehicles have on the grid..

\subsection{Modeling and Estimation of Battery State}

Last but not least, it is important to cover the topic of batteries since they are crucial for the electric and hybrid vehicles. In general, the state of charge in the battery is difficult to estimate and the contribution in D. Di Domenico, Y. Creff, E. Prada, P. Duchêne, J. Bernard and V. Sauvant-Moynot ("A Review of Approaches for the Design of Li-Ion BMS Estimation Functions") is a survey and comparison of different methods for estimating the state of charge. Designing and controlling batteries for vehicles is very challenging, where more basic research is needed and there are many research contributions appearing. An example is the summary of an experimentally oriented research project is given in P. Gyan, P. Aubret, J. Hafsaoui, F. Sellier, S. Bourlot, S. Zinola and F. Badin ("Experimental Assessment of Battery Cycle Life Within the SIMSTOCK Research Program") where the capacity and aging has been studied and gives both new results on the aging and points out new open areas for researchers to explore.

Along with charging and discharging there are also thermal effects are also contributing to the battery lifetime. Both the monitoring and control of thermal states are considered by L. Lefebre ("Smart Battery Thermal Management for PHEV Efficiency"). A similar motive lies behind the work in Xinfan Lin, Huan Fu, Hector E. Perez, Jason B. Siegel, Anna G. Stefanopoulou, Yi Ding and Matthew P. Castanier, ("Parameterization and Observability Analysis of Scalable Battery Clusters for Onboard Thermal Management"), that develops a model for the thermal state of a battery and a battery pack. Important contributions are that the model can be parametrized on-line and that the methodology presented is extensible to battery packs.

\section{CONCLUDING REMARKS}

All in all this OGST issue has a collection of papers that cover the areas of design and optimization of electric and hybrid vehicles and as such they show clear evidence of the exciting developments that are ongoing in the fields. Furthermore the contributions also exhibit the necessity and importance of an interplay between various scientific fields in the search and development of the environmentally friendly vehicle of the future.

Lars Eriksson

Vehicular Systems, Department of Electrical Engineering

Linköping Uninversity

58183 Linköping

Sweden 